Syntax Literate : Jurnal Ilmiah Indonesia p-ISSN: 2541-0849

e-ISSN : 2548-1398

Vol. 5, No. 2 Februari 2020

\title{
KEWENANGAN PEMERINTAH DAERAH DALAM PERATURAN, PENANGANAN KEMISKINAN DAN PEMBANGUNAN WILAYAH KOTA CIREBON BERBASIS MASYARAKAT
}

\author{
Yanto Irianto \\ Universitas Nahdlatul Ulama (UNU) Cirebon \\ Email: adv.yantoirianto@gmail.com
}

\section{Abstract}

The aims and objectives of this main research are to find out the local government authorities and find an ideal model of regulations regarding, poverty alleviation and community-based development of the City of Cirebon. The important reason this goal is realized is that most of the city is an urban center that has a lot of potential attractions for economic development. Therefore, there is little reason for the people of Cirebon to be living in poverty. But the irony is based on data from the World Bank and the Indonesian Statistics Agency (BPS), most people in Cirebon City are in poverty. Based on these reasons it leads to 2 (issues) that require further research is 1) what is the authority of the regional government in the regulation of the protection and management of the Cirebon City area based on the community and its model of regulation. The research method used is a normative research method. The discussion to the conclusion led to 1) that the regional government has the authority to regulate poverty reduction and the development of the Cirebon City area based on statutory regulations, starting from the 1945 Constitution of the Republic of Indonesia, Law no. 32 of 2004, Law No. 1 of 2011, Minister of Home Affairs Regulation No. 1 of 2008 concerning urban planning guidelines. 2) The model of the deal arrangement referred to is the arrangement regulated in the regional legal policy in the form of a regional regulation that specifically regulates the participation of the people of Cirebon in their participation in poverty reduction and the development of the City of Cirebon. With clear arrangements regarding the involvement of the people of the City of Cirebon, it is hoped that the problem of poverty in the people of the City of Cirebon can be overcome, so that justice and the welfare of the people of the City of Cirebon can be realized.

Keywords: Authority, protection, management, people of Cirebon City

\begin{abstract}
Abstrak
Tujuan dan target utama penelitian ini adalah untuk mengetahui kewenangan pemerintah daerah dan menemukan model ideal pengaturan tentang peraturan, penanggulangan kemiskinan dan pembangunan wilayah Kota Cirebon berbasis masyarakat. Alasan pentingnya tujuan ini diwujudkan bahwa sebagian besar dari kota tersebut merupakan pusat perkotaan yang memiliki dayatarik yang sangat potensial untuk pembangunan ekonomi. Oleh karena itu sedikit alasan bagi
\end{abstract}


masyarakat Kota Cirebon berada dalam taraf hidup kemiskinan. Namun ironi berdasarkan data Bank Dunia dan Badan statistik (BPS) Indonesia, sebagian besar masyarakat Kota Cirebon berada dalam taraf hidup kemiskinan. Berdasarkan alasan tersebut maka berujung pada 2 (persoalan) yang memerlukan penelitian lebih lanjut yaitu: 1) bagaimakah kewenangan pemerintah daerah dalam pengaturan perlindungan dan pengelolaan wilayah Kota Cirebon yang berbasiskan masyarakat dan model pengaturannya. Metode penelitian yang digunakan adalah metode penelitian normatif. Pembahasan sampai kesimpulan berujung pada: 1) bahwa pemerintah daerah memupunyai kewenangan untuk mengatur penanggulanagn kemiskinan dan pembangunan wilayah Kota Cirebon berdasarkan peraturan perundang-undangan yaitu mulai UUD RI Tahun 1945, UU No. 32 Tahun 2004, UU No. 1 tahun 2011, Peraturan Menteri Dalam Negeri No. 1 Tahun 2008 Tentang pedoman perencanaan Kawasan perkotaan. 2) Model deal pengaturan dimaksud adalah pengatuan yang diatur dalam kebijakan hukum daerah berbentuk peraturan daerah yang khusus mengatur mengenai peranserta masyarakat Kota Cirebon dalam keikutsertaannya dalam penanggulangan kemiskinan dan pembangunan Kota Cirebon. Dengan pengaturan yang jelas mengenai keterlibatan masyarakat Kota Cirebon memberi harapan masalah kemiskinan pada masyarakat Kota Cirebon dapat di atasi, sehingga keadilan dan kesejahteraan masyarakat Kota Cirebon dapat terwujud.

Kata kunci: Kewenangan, perlindungan, pengelolaan, masyarakat Kota Cirebon

\section{Pendahuluan}

Perkembangan pembangunan ekonomi Indonesia dewasa ini menunjukkan semakin mengalami kemajuan dimata dunia. Kemajuan ini ditandai dengan integrasi system ekonomi dunia. Ini merupakan efek dari perekonomian terbuka yang dianut yang dalam prakteknya tidak lepas dari hubungan internasional. Perdagangan internasional ini merupakan aktivitas pertukaran barang dan jasa yang harus dilandasi dengan kehendak sukarela dari masing-masing pihak yang bersangkutan. Perdagangan ini merupakam aspek penting dalam perekonomian negara dari setiap penjuru dunia.

Dukungan penting dari pemerintah dengan dibuatnya otonomi daerah yang mulai efektif pada tanggal 1 Januari 2001. Menurut Mudraj pembangunan ekonomi merupakan suatu proses dimana pemerintah berkolaborasi dengan masyarakat dalam mengelila sumber daya yang ada dan membentuk suatu pola dan lapangan pekerjaan baru dan merangsang perkembangan kegiatan ekonomi dalam daerah tersebut (Mudrajad, 2004). Pembangunan suatu negara maupun daerah memiliki indikator beberapa aktivitas perekonomian meningkat dengan ditandai meningkatnya pendapatan per kapita penduduk sehingga terjadi perbaikan tingkat kesejahteraan.

Dalam mencapai tujuan pembangunan masih ada tantangan. 25,9 juta orang yang hidup dibawah garis kemiskinan dari 264 juta penduduk Indonesia. Sekitar $20,19 \%$ dari seluruh penduduk masih rentan jatuh miskin. Data ini berdasarkan data Maret 2018 (Bank, 2019)

Sama halnya dengan BPS. Badan Pusat Statistik menyatakan pada September 2019, secara rata-rata rumah tangga miskin di Indonesia memiliki 4,58 orang anggota rumah tangga. Dengan demikian, besarnya Garis Kemiskinan per rumah tangga miskin secara rata-rata adalah sebesar Rp2.017.664,-/rumah tangga miskin/bulan ((BPS), 2019). 
Table 1

Jumlah Keluarga Miskin di Kota Cirebon Menurut Kelurahan Tahun 2014

\begin{tabular}{|c|c|c|}
\hline \multicolumn{2}{|c|}{ Wilayah Kelurahan } & \multirow{2}{*}{$\begin{array}{c}\begin{array}{c}\text { Jumlah Keluarga } \\
\text { Miskin }\end{array} \\
\mathbf{2 0 1 4} \\
2.222\end{array}$} \\
\hline \multirow{5}{*}{ Harjamukti } & Argasunya & \\
\hline & Kalijaga & 2.248 \\
\hline & Harjamukti & 1.294 \\
\hline & Kecapi & 871 \\
\hline & Larangan & 609 \\
\hline \multirow[t]{4}{*}{ Lemahwungkuk } & Pegambiran & 1.776 \\
\hline & Kesepuhan & 1.816 \\
\hline & Lemahwungkuk & 1.051 \\
\hline & Panjunan & 1.286 \\
\hline \multirow{4}{*}{ Pekalipan } & Jagasatru & 704 \\
\hline & Pulasaren & 675 \\
\hline & Pekalipan & 1.087 \\
\hline & Pekalangan & 720 \\
\hline \multirow[t]{5}{*}{ Kesambi } & Karyamulya & 1.694 \\
\hline & Sunyaragi & 1.011 \\
\hline & Drajat & 1.290 \\
\hline & Kesambi & 1.048 \\
\hline & Pekiringan & 811 \\
\hline \multirow[t]{4}{*}{ Kejaksan } & Kejaksan & 899 \\
\hline & Kebon Baru & 1.155 \\
\hline & Sukapura & 799 \\
\hline & Kesenden & 1.283 \\
\hline
\end{tabular}

Disisilain Badan Perencana Pembangunan Daerah (BAPEDA) Kota Cirebon terus berupaya mensejahterakan masyarakat dan terus mengembangkan pembanguanan dengan disosialisasikannya peraturan daerah nomor 10 Tahun 2018 Tentang Penyelenggaraan Kesejahteraan Sosial, Perwal Nomor 42 Tahun 2015 Tentang Mekanisme Koordinasi Penanggulangan Kemiskinan Di Kota Cirebon, dan perda Kota Cirebon Nomor 9 tahun 2008 tentang rencana pembangunan jangka Panjang (RPJPD) kota Cirebon tahun 2005-2025.

Berdasarkan uraian latar belakang di atas maka sangat relevan untuk dikaji lebih lanjut melalui penelitian yang berjudul "Kewenangan Pemerintah Daerah dalam Pengaturan Penanganan Kemiskinan dan Pembangunan Wilayah Kota Cirebon Berbasis Masyarakat". Rumusan Masalah Berdasarkan uraian dalam latar belakang di atas maka dapat dirumusakan. Bagaimanakah kewenangan dan model yang ideal Pemerintah Daerah dalam Pengaturan Penanganan Kemiskinan dan Pembangunan Wilayah Kota Cirebon Berbasis Masyarakat

\section{Metode Penelitian}

Menurut Peter mahmud Marzuki, "penelitian hukum adalah suau proses untuk menemukan aturan hukum, prinsip-prinsip hukum, maupun doktrin-doktrin hukum guna 
menjawab isu hukum yang dihadapi Menurut (Cohen, n.d.) mengemukakan bahwa "Legal research is an essential component of legal practice. It is the process of finding the law that governs an activity and materials that explain or analyze that law". (Soekanto, 2006) mengemukakan bahwa, dalam ilmu hukum teradapat dua jenis penelitian hukum terdapat, yaitu penelitian hukum normatif dan penelitian hukum sosiologis atau empiris. Metode penelitian hukum Normatif yang disebut juga sebagai penelitian hukum doktrinal dan juga disebut penelitian hukum perpustakaan. Penelitian ini terdiri dari peraturan-peraturan yang tertulis dan bahan-bahan hukum karena itu penelitian ini disebut penelitian hukum doktrinal sedangkan disebut sebagai penelitian perpustakaan atau studi dokumen karena penelitian ini lebih banyak dilakukan perpustakaan atau studi dokumen.

Dalam penelitian ini digunakan Jenis penelitian normatif, penelitian ini digunakan untuk membedah permasalahan yang terkait dengan kewenangan Pemerintah Daerah dalam pengaturan penanganan kemiskinan dan Pembangunan wilayah Kota Cirebon yang berbasis masyarakat. Dalam penelitian ini fokus kajiannya adalah pada kebijakan-kebijakan hukum Pemerintah maupun Pemerintah Daerah terkait dengan pengaturan penanganan kemiskinan dan pembangunan wilayah Kota Cirebon yang berbasis masyarakat. Selain hanya meneliti kebijakan-kebijakan dan aturan-aturan hukum yang terkait dengan pengaturan penanganan kemiskinan dan pembangunan wilaya Kota Cirebon yang berbasis masyarakat, juga ada model ideal pengaturan yang ditemukan terkait dengan peran masyarakat dalam pembangunan wilaya Kota Cirebon.

Sifat penelitian ini adalah kualitatif. Sifat penelitian yang kualitatif adalah jenis penelitian yang temuan-temuannya tidak diperoleh melalui prosedur statistik atau bentuk hitungan lainnya). Pada dasarnya penelitian kuallitatif didapat dari data dan bahan-bahan hukum yang meliputi, buku-buku, peraturan hukum, jurnal, hasil penelitian yang nantinya diramu lalu disajikan dalam suatu paparan deskripsi analisis.

\section{Hasil dan Pembahasan}

\section{A. Kewenangan Pemerintah Daerah dalam Pengaturan Penanganan Kemiskinan dan Pembangunan Wilayah Kota Cirebon}

Dalam Pembukaan UUD Negara Republik Indonesia Tahun 1945 alinea ke2 dan ke-4 jelas dipahami bahwa pemerintahan daerah merupakan alat kelengkapan negara yang betujuan untuk mewujudkan cita- cita negara. Untuk mewujudkan citacita negara, pemerintahan daerah diberi kewenangan untuk menjalankan seluruh urusan pemerintahan di daerah sesuai dengan kewenangan daerah. Merujuk pendapat (Hadjon, 2017) dan (Indroharto, 2000) yang menegaskan bahwa sumber kewenangan di dapat dari 3 (tiga) bentuk yaitu atribusi, delegasi dan mandat. Lebih lanjut (Hadjon, 2017) juga menyatakan bahwa kewenangan itu merupakan konsep inti dari hukum tata negara dan hukum administrasi negara yang pada dasarnya Pemerintah dalam mengambil suatu tindakan maka harus berdasarkan atas hukum yang berlaku. Hal ini dapat dipahami bahwa suatu tindakan pemerintah dikatakan sah, apabila tindakan itu berdasarkan atas hukum. Dengan demikian konsep 
kewenangan sangat kental dengan aspek legalitas. Secara singkat bahwa hukum memberikan suatu kewenangan kepada pemerintah untuk bertindak maupun tidak bertindak.

Kemampuan pemerintah untuk melakukan tindakan yaitu tindakan-tindakan hukum yang menimbulkan akibat-akibat hukum dan mencakup mengenai timbul dan lenyapnya akibat hukum tersebut. Memahami pendapat (Stroink \& Steenbeek, 1989) bahwa pemerintah dalam mendapatkan kewenangan hanya ada dua cara yaitu atribusi dan delegasi. Kewenangan atribusi berkenaan dengan penyerahan suatu wewenang baru, sedangkan delegasi adalah menyangkut pelimpahan wewenang yang telah ada.

Berdasarkan pada konsep kewenangan di atas maka berkaitan dengan kewenangan pemerintah daerah dalam pengaturan, penanganan kemiskinan dan pembangunan wilayah Kota Cirebon dapat dilihat dalam batas-batas kewenangan yang telah diatur dalam peraturan perundang-undangan. Dalam konteks pengaturan, setiap pembentukan peraturan hukum sebagai bentuk perlindungan hukum kepada masyarakat maka dasar kewenangan merupakan point penting dalam suatu proses pembentukan hukum. Selain mendasarkan pada dasar kewenangan suatu pembentukan hukum juga medasarkan pada fakta sosiologis atau kebutuhan masyarakat terhadap produk hukum tersebut.

Terkait dengan dasar kewenangan dalam pengaturan, penanganan kemiskinan dan pembangunan wilayah Kota Cirebon didasarkan pada Pasal 18 ayat (6) UUD Negara Republik Indonesia yang menegaskan bahwa pemerintah daerah berhak menetapkan peraturan daerah dan peraturan lain untuk melaksanakan otonomi dan tugas pembantuan. Dalam konteks ini pemerintah daerah mempunyai kewenangan untuk menetapkan peraturan daerah terkait dengan pengaturan, penanganan kemiskinan dan pembangunan wilayah Kota Cirebon yang berbasis pada masyarakat. Selanjutnya dasar kewenangan lain diatur dalam Perwal Nomor 42 Tahun 2015 Tentang Mekanisme Koordinasi Penanggulangan Kemiskinan Di Kota Cirebon, Tambahan Lembaran Negara Republik Indonesia Nomor 5490, dalam Pasal 1 angka 32 dengan tegas menyatakan bahwa Masyarakat adalah masyarakat yang terdiri dari Masyarakat Hukum Adat, Masyarakat Lokal, dan Masyarakat Tradisional yang bermukim di wilayah Kota Cirebon dan pulau-pulau kecil. Dalam konteks ini UU 1 tahun 2014 secara legal mengatur masyarakat untuk ikut berpartisipasi dalam perlindungan dan pengelolaan wilayah Kota Cirebon. Hal ini menandakan bahwa masyarakat diberi otoritas untuk ikut menentukan kebijakan dan penyelenggaraan yang berkaitan dengan pengaturan, penanganan kemiskinan dan pembangunan wilayah Kota Cirebon. Konteks dasar kewenangan dalam membentuk kebijakan hukum terutama peraturan hukum juga terdapat dalam Undang-Undang Nomor 12 Tahun 2011 tentang Pembentukan Peraturan Perundang-undangan (Lembaran Negara Republik Indonesia Tahun 2011 Nomor 82, Tambahan Lembaran Negara Republik Indonesia Nomor 5234, yang mengatur 
teknis pembentukan kebijakan hukum. Dalam membentuk kebijakan hukum ada 3 (tiga) unsur yang harus terpenuhi yaitu unsur filosofis, sosiologis dan yuridis.

Dalam menelaah kewenangan pemerintah daerah untuk mengatur perlindungan dan pengelolaan wilayah Kota Cirebon yang berbasisi masyarakat perlu mempertimbangkan aspek filosofisnya yaitu tujuan dan arah pengaturan dari suatu peraturan yang dibentuk (pengaturan, penanganan kemiskinan dan pembangunan wilayah Kota Cirebon yang berbasis masyarakat). Selanjutnya aspek sosiologis yaitu dilihat dari aspek kebutuhan dari masyarakat Kota Cirebon yang memang membutuhkan pengaturan terkait partisipasi masyarakat Kota Cirebon dalam pengelolaan wilayah Kota Cirebon sebagaimana telah diatur dalam peraturan yang lebih tinggi (UU 1 tahun 2014 dan permendagri 40 tahun 2014). Aturan ini dengan tegas menyatakan bahwa ketika melakukan perlindungan hukum dan pengelolaan 22 wilayah Kota Cirebon, masyarakat wajib ikut berpatisipasi. Hal ini juga didasarkan bahwa selama ini masyarakat Kota Cirebon selalu berada dalam lingkup kemiskinan dan kesulitan perekonomian. Dengan demikian aturan-aturan yang terbitan terbaru lebih banyak mulai melindungi masyarakat Kota Cirebon dan diberikan otoritas oleh peraturan hukum untuk mengelola wilayah Kota Cirebonnya sesuai dengan kearifan lokalnya. Untuk melihat kewenangan pemerintah daerah dalam membentuk hukum adalah pada Undang-Undang Nomor 23 Tahun 2014 tentang Pemerintahan Daerah (Lembaran Negara Republik Indonesia Tahun 2014 Nomor 244, Tambahan Lembaran Negara Republik Indonesia Nomor 5587) sebagaimana telah diubah beberapa kali terakhir dengan Undang-Undang Nomor 9 Tahun 2015 Tentang Perubahan Kedua Atas Undang-Undang Nomor 23 Tahun 2014 Tentang Pemerintahan Daerah (Lembaran Negara Republik Indonesia Tahun 2015 Nomor 58, Tambahan Lembaran Negara Republik Indonesia Nomor 5679), yang dengan tegas menyatakan bahwa antara pemerintah pusat, provinsi dan kabupatem/Kota mempunyai kewenangan yang berbeda untuk mengurus daerahnya berdasarkan pada otonomi daerah. Dalam era otonomi daerah, masyarakat perlu dilibatkan agar dapat menumbuhkembangkan dan sekaligus memelihara tradisi, baik secara individu maupun secara kelompok (Dwirayani, 2017). Sebagaimana disebutkan dalam Pasal 11 UU 23 tahun 2014 yang menegaskan bahwa klasifikasi urusan pemerintahan dibagi menjadi 3 (tiga) yaitu: 1 . urusan pemerintahan absolute (urusan pemerintah pusat) 2. urusan pemerintahan konkuren (urusan pemerintah provinsi, kabupaten/kota), dan 3. Urusan pemerintahan umum (Urusan Pemerintahan yang menjadi kewenangan Presiden sebagai kepala pemerintahan).

Selanjutnya terkait dengan kewenangan pemerintah dalam penanganan kemiskinan dan pembangunan wilayah Kota Cirebon yang berbasis masyarakat masuk dalam pembagian urusan konkuren yang merupakan kewenangan pemerintah provinsi dan pemerintah kabupaten/kota. Penanggulangan kemiskinan dan pembangunan wilayah Kota Cirebon termasuk dalam pembangian urusan di bidang kesejahteraan yang pengaturannya terdapat dalam Pasal 34 ayat (1). Berdasarkan pada UU No 11 tahun 2009 menjadi jelas kewenangan pemerintah 
daerah dalam mensejahterakan wilayah Kota Cirebon. Dalam penanggulangan kemiskinan wilayah Kota Cirebon sebagaimana disebutkan dalam perwal Nomor 42 Tahun 2015 Tentang Mekanisme Koordinasi Penanggulangan Kemiskinan Kota Cirebon, aspek penting yang perlu diperhatikan adalah peran masyarakat Kota Cirebon dalam keterlibatannya untuk ikut serta dibidang penanganan kemiskinan wilayah Kota Cirebon. Dalam melakukan kegiatan penanggulangan kemiskinan wilayah Kota Cirebon, di bentuk kelompok program bantuan sosial terpadu berbasis keluarga (nilai-nilai hukum yang hidup dalam masyarakat). Mengenai penanganan kemiskinan wilayah Kota Cirebon juga mendapat pengaturan melalui Peraturan Menteri Sosial Republik Indonesia Nomor 15 tahun 2018 Tentang Sistem Layanan dan Rujukan Terpadu untuk Penanganan Fakir Miskin dan Orang Tidak Mampu. Dalam Peraturan Menteri Sosial ini, konteks penanggulangan yang dimaksud adalah merujuk kepada bab 1 pasal 1 ayat 1 . Hal ini lebih ditekankan pada bagaimana pemerintah merencanakan untuk membuat kebijakan dan prosedur maupun kesepakatan dalam peningkatan ekonomi wilayah Kota Cirebon sesuai dengan kewenangannya.

Sedangkan dalam peraturan daerah kota Cirebon Nomor 9 tahun 2018 Tentang Sistem Perencanaan Pembangunan Daerah Kota Cirebon lebih menegaskan bahwa dalam pengelolaan wilayah Kota Cirebon, peran serta masyarakat Kota Cirebon memiliki arti penting. Adapun bentuk keikutsertaan masyarakat dalam pembangunan wilayah Kota Cirebon adalah pelaksanaan dan pengawasan. Dalam konteks ini masyarakat Kota Cirebon mempunyai peran penting dan diberikan otoritas oleh peraturan perundang-undangan untuk mengelola wilayah Kota Cirebon sesuai dengan kearifan lokal dan hukum adatnya.

Untuk pembangunan wilayah Kota Cirebon yang tepat dan berhasil guna, maka pemerintah sesuai dengan kewenangannya berkewajiban melakukan pemberdayaan masyarakat berdasarkan potensi dan karakteristik, serta analisa kebutuhan masyarakat dengan mempertimbangkan kondisi sosial, ekonomi, budaya, dan lingkungan. Pemberdayaan masyarakat dilakukan sebagai upaya untuk dorongan, atau memberikan bantuan kepada masyarakat Kota Cirebon agar mampu menentukan pilihan yang terbaik dalam memanfaatkan sumber daya Kota Cirebon. Selain pemberdayaan yang diberikan oleh pemerintah, pembinaan juga merupakan unsur penting dalam pengelolaan wilayah Kota Cirebon. Dalam pembinaan ini pemeritah berdasarkan kewenangannya memberikan bimbingan, pendidikan, pelatihan, penyuluhan dan sosialisasi terkait dengan pembangunan wilayah Kota Cirebon yang baik dan berhasil guna.

Tujuan dilakukan pemberdayaan dan pembinaan ini adalah agar masyarakat Kota Cirebon memiliki kemampuan dan kemandirian dalam pengelolaan wilayah Kota Cirebon, untuk meningkatkan efektifitas dan keberlanjutan dalam pemanfaatan wilayah Kota Cirebon dengan memperkuat nilai-nilai kearifan lokal untuk proses pembangunan bangsa khususnya pembangunan wilayah Kota Cirebon yang berkelanjutnan. Berdasarkan kewenangan berdasarkan peraturan perundang- 
undangan yang telah di uraikan di atas, maka pemerintah daerah mempunyai dasar kewenangan untuk membentuk pengaturan hukum terkait dengan perlindungan dan pengelolaan wilayah Kota Cirebon berbasis mayarakat.

\section{B. Model Ideal Pengaturan Penanggulangan Kemiskinan dan Pembangunan Wilayah Kota Cirebon yang Berbasis pada Masyarakat}

Sebagaimana diatur dalam Peraturan Daerah Kota Cirebon Pasal 6 angka 1 UU Nomor 9 tahun 2019 tentang Peraturan Daerah Kota Cirebon bahwa yang dimaksud Wilayah Kota Cirebon merupakan jalur utama transportasi dari Jakarta menuju Jawa Barat, Jawa Tengah, yang melalui daerah utara atau pantai utara (pantura), dengan lketak geografis yang sangat strategis. selanjutnya wilayah Kota Cirebon adalah daerah yang terdiri dari darat dan laut. Apabila melihat penelusuran data bahwa angka jumlah penduduk miskin Kota Cirebon cukup besar, yakni mencapai 26.349 persen dari jumlah total penduduk miskin Indonesia. Laju perekenomian di Kota Cirebon terdapat perbedaan keadaan dan perkembangan perekonomian masyarakat di daerah Kota Cirebon dan masyarakat di daerah Kabupaten. Permasalahan-permasalahan sosial di daerah Kota Cirebon sangat kompleks. Permasalahan-permasalahan kompleks tersebut timbul secara langsung maupun tidak langsung terkait dengan kemiskinan masyarakat Kota Cirebon, kebijakan yang tidak tepat, rendahnya penegakan hukum (law enforcement), dan rendahnya kemampuan sumber daya manusia (SDM).

Permasalahan di Kota Cirebon di atas bila dikaji lebih lanjut memiliki akar permasalahan yang mendasar. Menurut Dahuri ada lima faktor, yaitu pertama tingkat kepadatan penduduk yang tinggi dan kemiskinan, kedua konsumsi berlebihan dan penyebaran sumber daya yang tidak merata, ketiga kelembagaan, keempat, banyaknya kawasan pemasaran dan kelima kegagalan sistem ekonomi dan kebijakan dalam menilai ekosistem alam.

Berdasarkan hasil pengamatan dan hasil studi terkait dengan daerah Kota Cirebon menunjukan bahwa perencanaan dan pelaksanaan pembangunan sumber daya Kota Cirebon yang selama ini dijalankan bersifat sektoral dan terpilah-pilah, padahal karakteristik ekosistem Kota Cirebon yang secara ekologis saling terkait. Dengan demikian pengelolaan sumberdaya wilayah Kota Cirebon secara optimal dan berkelanjutan hanya dapat diwujudkan melalui pendekatan terpadu dan holistik.

Pengelolaan wilayah Kota Cirebon terpadu dinyatakan sebagai proses pemanfaatan sumberdaya Kota Cirebon serta ruang yang memperhatikan aspek konservasi dan keberlanjutannya. Adapun konteks keterpaduan meliputi dimensi sektor, ekologis, pemerintahan, antar bangsa dan negara, dan disiplin ilmu. Masyarakat yang tinggal di wilayah Kota Cirebon (masyarakat Kota Cirebon) menjadi bagian yang terpenting dalam ekosistem Kota Cirebon. Komponen terbesar dari masyarakat Kota Cirebon adalah pedagang dan buruh yang memiliki ketergantungan yang besar terhadap keberlanjutan terhadap pasar, penginapan dan swalayan Kota Cirebon. Selain itu masyarakat Kota Cirebon memiliki peran 
penting dalam pembangunan berkelanjutan di wilayah Kota Cirebon. Oleh karena itu unsur penting dalam pembangunan berkelanjutan adalah partisipasi masyarakat (pembangunan berbasisi masyarakat) dalam konteks ini adalah partisipasi masyarakat Kota Cirebon.

Pembangunan berbasisi masyarakat secara sederhana dapat diartikan sebagai pembangunan yang mengacu pada kebutuhan masyarakat, direncanakan dan dilaksanakan oleh masyarakat dengan sebesar-besarnya memanfaatkan sumber daya alam yang ada dan dapat diakses oleh masyarakat setempat. Oleh karena itu pembangunan berbasisi masyarakat seharusnya pembangunan yang berangkat dari kebutuhan masyarakat dan bukannya dirumuskan oleh orang luar atau elit masyarakat yang merasa tahu dan pandai untuk merumuskan pembangunan yang cocok bagi masyarakatnya.

Menurut Aprillia Theresia dkk, menyatakan bahwa pembangunan berbasis masyarakat berarti pembangunan harus berbasis sumberdaya lokal, berbasis pada modal sosial, berbasis pada budaya lokal, berbasis pada kearifan lokal yang dimiliki dan diyakini oleh masyarakat setempat. Selanjutnya Aprillia Theresia juga mengatakan bahwa pembangunan berbasis masyarakat seringkali dikonotasikan dengan pembangunan dari bawah yang lebih baik dari pembangunan dari atas.

Memahami pengelolaan sumber daya alam berbasis masyarakat adalah sama dengan memahami partisipasi masyarakat dalam pengelolaan wilayah Kota Cirebon. Partisipasi masyarakat Kota Cirebon dalam pengelolaan sumber daya Kota Cirebon dapat dikatakan sebagai suatu proses pemberian wewenang, tanggung jawab dan kesempatan kepada masyarakat untuk mengelola suberdayanya sendiri berdasarkan kebutuhan dan keinginan serta tujuan aspirasinya. Keberhasilan pengelolaan wilayah Kota Cirebon yang berbasis masyarakat dipengaruhi oleh dua (2) macam yaitu : 1. Konsensus yang jelas dari tiga pelaku utama, yaitu pemerintah, masyarakat Kota Cirebon, dan peneliti (sosial, ekonomi, dan sumberdaya); 2. Pemahaman yang mendalam dari masing-masing pelaku utama akan peran dan tanggung jawabnya dalam mengimplementasikan program pengelolaan berbasis masyarakat.

Menurut Tjokrowinoto bahwa ciri-ciri pembangunan yang berpusat pada rakyat (masyarakat) yaitu :

1. Prakarsa dan proses pengambilan keputusan untuk memenuhi kebutuhan masyarakat tahap demi tahap harus diletakkan pada masyarakat itu sendiri.

2. Fokus utamanya adalah meningkatkan kemampuan masyarakat untuk mengelola dan memobilisasikan sumber-sumber yang terdapat di komunitas untuk memenuhi kebutuhan mereka.

3. Pendekatan ini mentoleransi variasi lokal dan karenanya, sifatnya fleksibel menyesuaikan dengan kondisi lokal.

4. Di dalam melaksanakan pembangunan, pendekatan ini menekankan pada proses social learning yang didalamnya terdapat interaksi kolaboratif antara birokrasi dan komunitas. 
5. Proses pembentukan jejaring (networking) antara birokrasi dan lembaga swadaya masyarakat, satuan-satuan organisasi tradisonal yang mandiri, merupakan bagian integral dari pendekatan ini, baik untuk meningkatkan kemampuan mereka mengidentifikasi dan mengelola perbagai sumber, maupun untuk menjaga keseimbangan antara struktur vertikal maupun horizontal. Melalui proses networking ini diharapkan terjadi simbiose antara strukturstruktur pembangunan di tingkat lokal.

Selanjutnya menurut Dahuri menyatakan bahwa ada lima prinsip dasar yang penting untuk dilaksanakan dalam pengelolaan yang berbasis masyarakat yaitu:

1. Pemberdayaan

2. Pemerataan akses dan peluang,

3. Ramah lingkungan dan lestari

4. Pengakuan terhadap pengetahuan dan kearifan local

5. Kesetaraan jender.

Tampaknya prinsip-prinsip yang diperkenalkan oleh Dahuri tidak berbeda jauh dari prinsip yang dianut dalam peraturan peundang-undangan yang khusus mengatur wilayah Kota Cirebon. Sebagaimana di sebutkan dalam UU Nomor 9 Tahun 2018 yang dengan tegas menyatakan bahwa Pemanfaatan ruang dan sumber daya perkotaan Kota Cirebon pada wilayah masyarakat hukum adat oleh masyarakat hukum adat menjadi kewenangan masyarakat hukum Adat setempat. Hal ini menunjukan bahwa ada peran penting dari masyarakat dalam konteks ini masyarakat hukum adat dalam aspek perlindungan dan pengelolaan wilayah Kota Cirebon berdasarkan hukum adat dan kebiasaannya.

Merujuk prinsip dari Dahuri di atas, bahwa dalam konteks perlindungan dan pengelolaan wilayah Kota Cirebon, pemberdayaan, adanya akses dan peluang ramah lingkungan pengakuan kearifan lokal dan keadilan gender tampaknya bersesuaian dengan nilai-nilai hukum adat. Pemberdayaan, dalam konteks ini pemberdayaan masyarakat Kota Cirebon sangat diperlukan untuk pembangunan wilayah Kota Cirebon yang berkelanjutan dan bertujuan untuk mengarahkan terwujudnya perbaikan teknis pengelolaan dan perbaikan wilayah Kota Cirebon.

Dalam Peraturan Pemerintah Daerah no 9 tahun 2018 menegaskan bahwa untuk mendukung proses pembangunan Wilayah Kota Cirebon maka harus memperkuat nilai-niai kearifan lokal. Tampaknya terkait dengan pengelolaan wilayah Kota Cirebon yang diberikan otoritas pada mayarakat, maka model yang tepat digunakan mengenai pembangunan wilayah Kota Cirebon adalah model pembangunan wilayah berbasis masyarakat, sedangkan model pengaturannya adalah diatur dalam bentuk kebijakan pemerintah daerah yaitu Peraturan Daerah. Oleh karena pentinganya keterlibatan masyarakat Kota Cirebon dengan nilai nilai kearifan local nya maka untuk mendapatkan kepastian hukum, peranserta masyarakat tersebut harus dituangkan dalam kebijakan-kebijakan hukum pemerintah daerah yaitu dalam bentuk peraturan daerah 


\section{Kesimpulan}

Berdasarkan uraian di atas maka dapat disimpulkan sebagai berikut:

1. Dasar kewenangan pemerintah daerah dalam Peraturan, Penanganan Kemiskinan dan Pembanguanan wilayah Kota Cirebon adalah terdapat dalam UUD Negara Rpublik Indonesia Tahun 1945, Perwal Kota Cirebon Nomor 42 Tahun 2015, Undang-Undang Nomor 23 Tahun 2014 tentang Pemerintahan Daerah, undangundang No. 11 tahun 2009 menjadi jelas kewenangan pemerintah daerah dalam mensejahterakan wilayah Kota Cirebon.

2. Model ideal pengaturan perlindungan dan pengelolaan wilayah Kota Cirebon yang berbasis pada masyarakat adalah model yang melibatkan masyarakat Kota Cirebon dalam perlindungan dan pengelolaan sumber daya Kota Cirebon yang berlandaskan pada kearifan lokal. Keikutsertaan masyarakat Kota Cirebon dalam pengelolaan sumberdaya Kota Cirebon berarti suatu proses pemberian wewenang, tanggung jawab dan kesempatan kepada masyarakat untuk mengelola sumberdayanya sendiri berdasarkan kebutuhan dan keinginannya. Untuk lebih menuju kepastian hukum maka model perlindungan dan pengelolaan tersebut harus dituangkan dalam peraturan hukum dengan bentuk peraturan daerah. 


\section{BIBLIOGRAFI}

Badan Pusat Statistik. (2019). Persentase Penduduk Miskin September 2019 turun menjadi 9,22 persen. Retrieved from https://www.bps.go.id/pressrelease/2020/01/15/1743/persentase-penduduk-miskinseptember-2019-turun-menjadi-9-22-persen.html

Bank, The World. (2019). Bank Dunia Di Indonesia. Retrieved from https://www.worldbank.org/in/country/indonesia/overview

Cohen, Morris L. (n.d.). dan Kent C. Olson. 2016. Legal Research in a Nutshell.

Dwirayani, Dina. (2017). Analisis Strategi Pengembangan Lumbung Pangan Desa Untuk Ketahanan Pangan. Syntax Literate; Jurnal Ilmiah Indonesia, 2(10), 14-26.

Hadjon, Philipus M. (2017). tentang Wewenang. Yuridika, 7(5-6).

Indroharto, S. H. (2000). Usaha-Usaha memahami Undang-Undang Peradilan Tata Usaha Negara. Buku II, Pustaka Sinar Harapan, Jakarta.

Mudrajad, Kuncoro. (2004). Otonomi dan Pembangunan Daerah; Reformasi, Perencanaan, Strategi, dan Peluang. Erlangga. Jakarta.

Soekanto, Soerjono. (2006). Pengantar penelitian hukum. Penerbit Universitas Indonesia (UI-Press).

Stroink, Frederik August Maximiliaan, \& Steenbeek, Jan Gerhard. (1989). Inleiding in het staats-en administratief recht. Samsom HD Tjeenk Willink. 